\title{
SOME SATELLITE-TRACKED ICEBERG DRIFTS IN THE ANTARCTIC $*$
}

\author{
by \\ Torgny E. Vinje \\ (Norsk Polarinstitutt, 1330 Oslo Lufthavn, Norway)
}

\section{ABSTRACT}

The drift of eight tabular icebergs is discussed. In spite of large differences in the vertical dimension, the various icebergs seem to react in a similar manner to wind effects in areas covered with sea ice. Measurements indicate that it takes between one and five years for an iceberg to move into the westerlies from the coastal areas between about $50^{\circ} \mathrm{E}$. and the Antarctic Peninsula. The drift of the icebergs reflects the integrated current effects in the upper 200-300 m, and may thus also give information about the transport of water masses.

\section{INTRODUCTION}

Until recently, little has been known about the movement of Antarctic icebergs apart from what can be estimated from the general circulation of the oceans. Since 1966, satellite technology has changed this situation, in that giant icebergs can be identified on satellite images. Many trackings are now made on a more or less regular basis by the U.S. Navy-NOAA Joint Ice Center at Suitland, Maryland, U.S.A. Reports on the life history of the giant iceberg, Trolltunga, have been compiled by Vinje (1977), Swithinbank and others (1977), Strübing (1978), and McClain (1978), and the ultimate fate of this berg is indicated by the observation of an accumulation of numerous icebergs, including tabular ones, encountered at position $43^{\circ} \mathrm{S}, 11^{\circ} \mathrm{E}$. in December 1978 (Vinje 1979).

In 1972 the French started to deploy satellite-positioned automatic buoys on tabular icebergs in the east wind drift along the coast of east Antarctica. This experiment gave the first weather-independent data on iceberg drifts (ichernia 1974). In 1978, an automatic Nimbus-6/RAMS satellite station was placed on an iceberg which drifted for about one year from the central part of the Weddell Sea into the areas south of Bouvetфya (Vinje 1979). In connection with the First GARP Global Experiment (FGGE) in 1979, seven automatic buoys transmitting via the Tiros-N/ Argos system were deployed on tabular icebergs by the Norwegian Antarctic Research Expedition
(NARE) 1978-79 to gain further information on the movement of icebergs into, and within, the west wind drift.

\section{SOME FEATURES OF THE OBSERVED DRIFT PATTERN} The drift in the eastern part of the Wedde11 Sea suggests that the coastal south-westward drift extends out to $100-200 \mathrm{~km}$ from the coast (Figs. 1 and 3 ). It may also be seen that the distance over which the drift changes into an opposite, or northerly, direction is relatively narrow. In the area under discussion and in a region east of it, a polynya of a considerable size $\left(0.25 \times 10^{6} \mathrm{~km}^{2}\right)$ with a very small sea-ice concentration has been observed each winter in 1974, 1975, and 1976 (Fig.2). According to calculations made by Romanov (1976), this is also an area which shows maximum divergence in the wind field. In the northern part of the Weddell Sea, the observations show that a considerable variation in the drift direction may take place from year. to year. As the drift of the icebergs represents the integrated current effects in the uppermost $200-300 \mathrm{~m}$, this variation must have marked effects upon the circulation over extensive areas. A nine-day average of observed drift speed is shown in Figure 3.

Further east, a marked reduction is observed in the drift speed when iceberg no. 0 , tracked in 1978, meandered into the area about $60^{\circ} \mathrm{S}$., between 15 and $0^{\circ} \mathrm{W}$. This area was formerly reported to have had a relatively high concentration of sea ice even in January (Hansen 1936). It also partly coincides with a region where the currents are reported to be variable (Treshnikov 1964). However, when the iceberg moves eastward out of this region, there is a marked increase in the drift speed, to a maximum of $0.5 \mathrm{~m} \mathrm{~s}^{-1}$ over a period of $12 \mathrm{~d}$. This increase could be due to a possible splitting-up of the berg at that time.

However, further north the iceberg moving eastward from Bouvet $\phi y a$ showed an average speed of $0.3 \mathrm{~m} \mathrm{~s}^{-1}$ with a maximum of $0.51 \mathrm{~m} \mathrm{~s}^{-1}$ over a five-day period, and this is similar to the velocities observed on iceberg no.0 further south. The time taken for an iceberg such as 
Trolltunga to pass into the westerlies at $60^{\circ} \mathrm{S}$. is about 5.5 years (subtracting the five years it was grounded off Berkner Island). The observations show further that icebergs breaking away from the Filchner Ice Shelf may pass into the west wind drift within two to three years. For icebergs in the central part

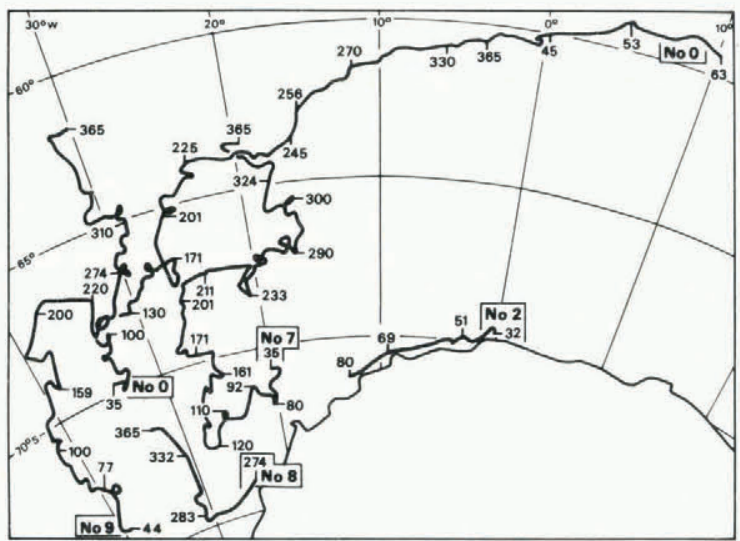

Fig. 1a. Some selected drift tracks of icebergs instrumented in the Wedde 11 Sea, no.0 in February 1978 and the rest in February-March 1979. Note the similarity in the drift which may be observed over large areas (nos.9 and 7) and note also the considerable difference in the drift which may take place from year to year in the northern part of the Wedde11 Sea. The Julian days are noted along each track.

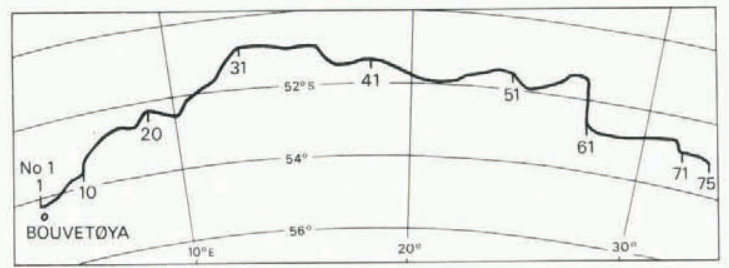

Fig. 1b. Drift of iceberg no.1 instrumented from Bouvet $\varnothing$ ya 1979 .

of the Wedde11 Sea, the northward drift to the 60 th parallel takes about one year. The drift speed of icebergs in the east wind drift along the coast of Dronning Maud Land east of $0^{\circ}$ is very high according to Tchernia (1974). It takes only about nine months for an iceberg to move from $50^{\circ} \mathrm{E}$. into the Weddel1 Sea. Measurements accordingly indicate that between one and five years elapse before icebergs breaking away from the ice shelves between $50^{\circ} \mathrm{E}$. and the Antarctic Peninsula enter into the westerlies at $60^{\circ} \mathrm{S}$. Provided there are no groundings, icebergs leaving the north-western coast of Dronning Maud Land and the northern part of the peninsula are likely to transfer most rapidly. Icebergs from the latter area may, however, take a more northerly course and start moving eastward after they have passed South Georgia, as suggested by the movement of Trolltunga.
SEA ICE AND ICEBERG DRIFT

In connection with other special investigations during NARE 1978-79, the physical dimensions of a large number of icebergs were measured (Orheim 1980). In

Table I these parameters are given for the eight instrumented icebergs.

Figure 4 shows an example of the great similarity which may be observed in the motions over relatively large areas when icebergs are surrounded by sea ice of high concentration. There is a nearly perfect parallelism in the movement, and this is noteworthy, because the two larger icebergs (nos.5 and 7) have a vertical extension four times greater than the smallest one (no.23) (cf. Table I). However, the surface currents in the area are weak and variable (Treshnikov 1964), and the parallelism may therefore indicate a dominance of the steering influence of the sea-ice movement which in turn is controlled by the wind. A more direct comparison is represented in Figure 5, which shows the drift of sea ice (Ackley, in press) in relation to the movement of an iceberg (no.9) in the Weddell Sea. The comparison indicates a general correspondence in the main drift. The average speed (net displacement time), over the period considered is $0.084 \mathrm{~m} \mathrm{~s}^{-1}$ for the iceberg and $0.069 \mathrm{~m} \mathrm{~s}^{-1}$ for the sea ice.

According to the above similarities, the outflow of sea ice from the Weddell Sea can be approximated. The mean northward speed in 1979 of the four icebergs, averaged over the distance between 72 and $62^{\circ} \mathrm{S}$., amounts to $0.048 \mathrm{~m} \mathrm{~s}^{-1}$. We consider the flux across the 62 nd parallel between $15^{\circ} \mathrm{W}$. and the tip of the Antarctic Peninsula for the period from April to December

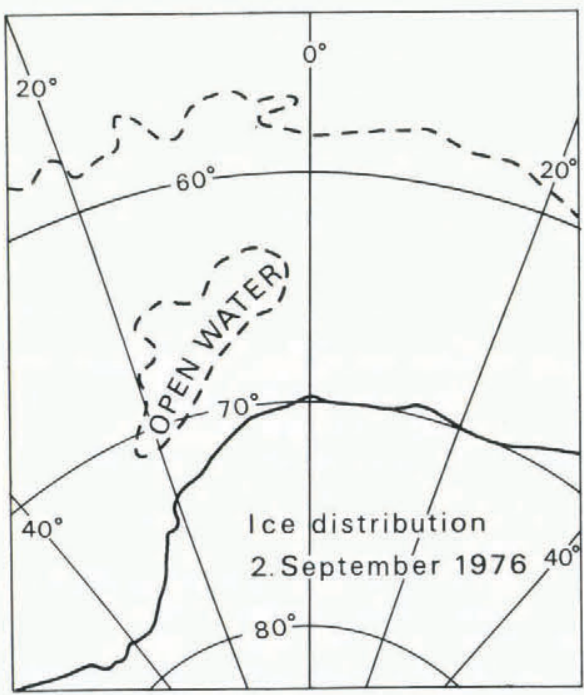

Fig. 2. An extensive area with a relatively small concentration of sea ice was observed off Dronning Maud Land during the winters of 1974,1975 , and 1976. The polynya seemed to move slightly westward from year to year (U.S. Navy-NOAA sea ice charts). Comparison with Figures 1 and 3 shows that the icebergs have a tendency to move around this area. 


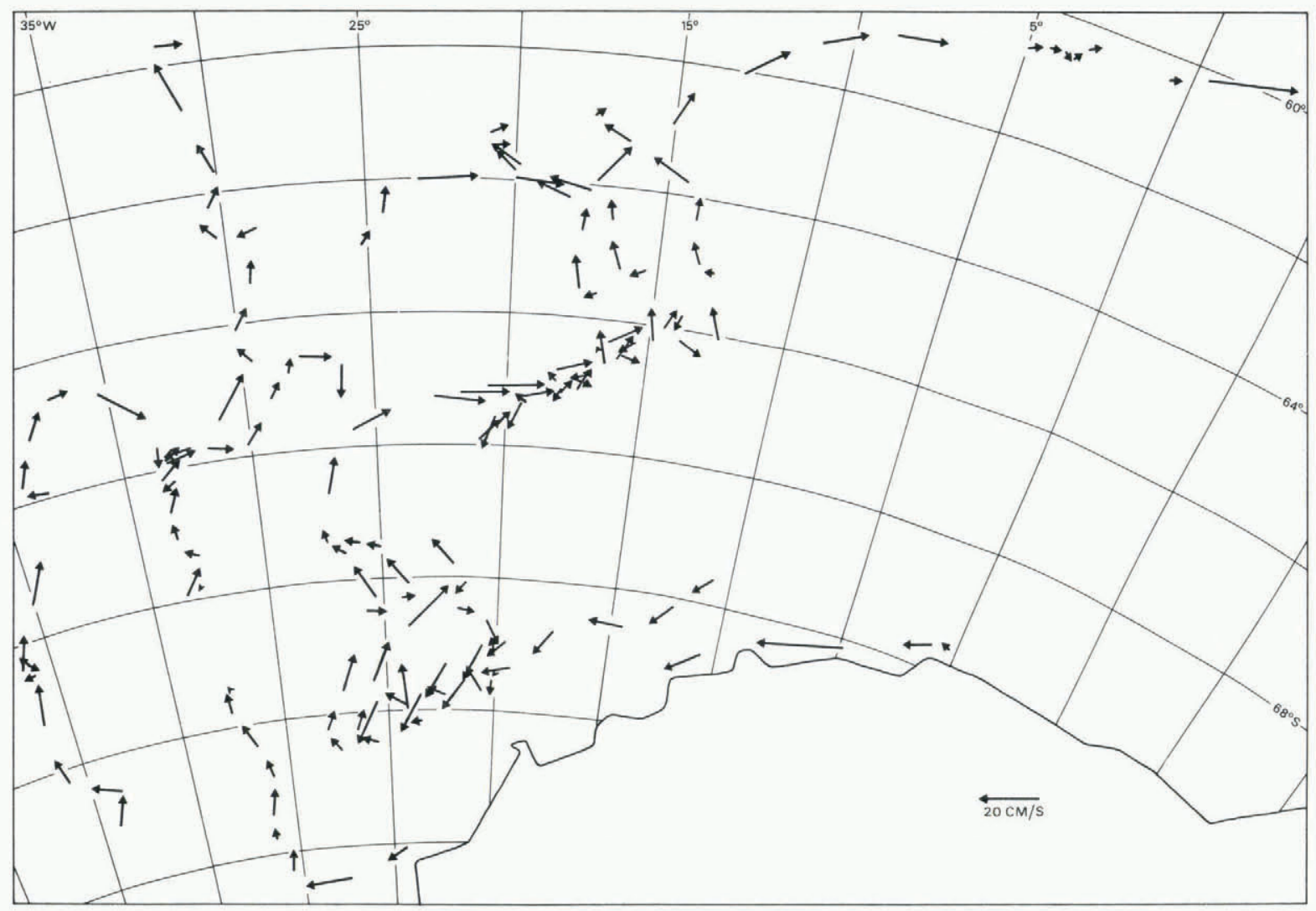

Fig. 3. Nine-day averages of the drift of the seven icebergs instrumented in the Weddell Sea.

TABLE I. DIMENSIONS OF OBSERVED ICEBERGS (The number of each iceberg corresponds to the NARE numbering referred to in Figure 1.)

\begin{tabular}{|c|c|c|c|c|c|}
\hline Iceberg no. & Period of observed drift & $\begin{array}{l}\text { Thickness } \\
\text { (m) }\end{array}$ & $\begin{array}{l}\text { Length } \\
\text { (m) }\end{array}$ & $\begin{array}{l}\text { Width } \\
(\mathrm{m})\end{array}$ & $\begin{array}{l}\text { Sail height } \\
\text { (m) }\end{array}$ \\
\hline 0 & 4 Feb 78 to 2 Mar 79 & & 900 & 500 & $40-50 *$ \\
\hline 1 & 1 Jan 79 to 16 Mar 79 & $300^{*}$ & 350 & 120 & 45 \\
\hline 2 & 1 Feb 79 drifting & 200 & 1030 & 370 & 33 \\
\hline 5 & 3 Feb 79 & 260 & 860 & 840 & 40 \\
\hline $7++$ & 4 Feb 79 & 210 & 1030 & 900 & 34 \\
\hline 8 & progress & 340 & 740 & 480 & 50 \\
\hline 9 & 13 Feb 79 & 200 & 2900 & & 35 \\
\hline 23 & $1 \operatorname{Mar} 79$ & 60 & 700 & 440 & 13 \\
\hline
\end{tabular}

* Estimated

†+ Iceberg with platform provided by Iceberg Transport International Ltd. 
and a corresponding distance from $30^{\circ} \mathrm{W}$. for the remaining three summer months. The estimation suggests an outflow of sea ice in 1979 of roughly $2.5 \times 10^{6} \mathrm{~km}^{2}$. In comparison, it can be mentioned that this area is about 2.5 times the estimated area of sea ice which passes through the Fram Strait from the Arctic Ocean each year (Vinje and Finnekåsa, in press). As the drift of the icebergs is closely related to the integrated current effect in the upper 200-300 m, the ice drift may also give information on large-scale water transport.

\section{FURTHER STUDIES}

This measuring programme is continuing at present. There is a variety of different problems which may be studied when the drift of these icebergs has finished, and maps over the atmospheric pressure field become available. For instance, the correlation between the iceberg drift and the geostrophic wind field in various areas with or without ice, relationships between the geostrophic and the surface wind measured on one of the icebergs in the group consisting of three bergs (Fig.4), the effect of waves, which were recorded at Bouvetфya, and possibly also the tidal effects in various areas.

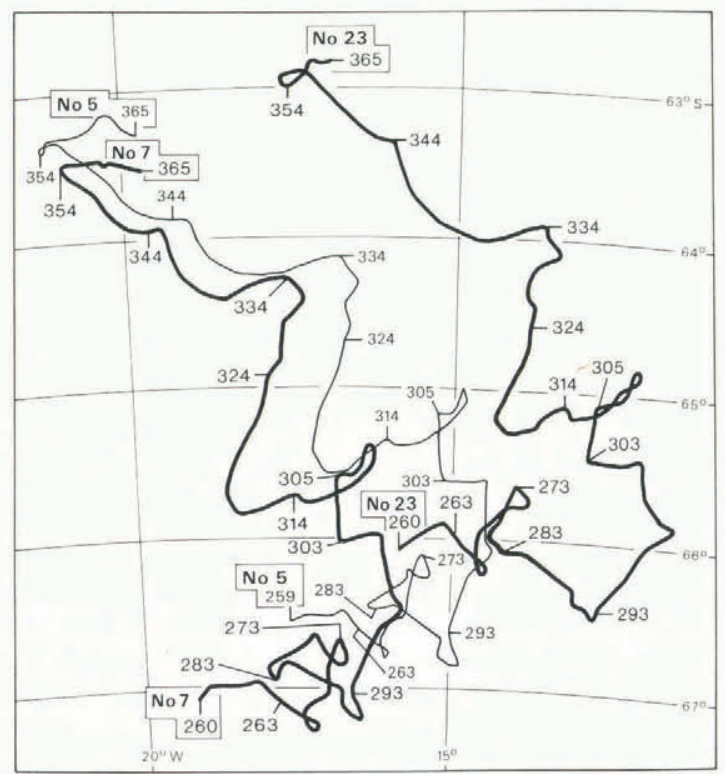

Fig. 4. The movements of three icebergs in the northern part of the Weddell Sea. The seaice concentration was mainly between $6 / 8$ and $8 / 8$ most of the time. U.S. Navy-NOAA ice charts give $3 / 8-5 / 8$ for the 20 December and open water for 27 December 1979. As icebergs nos. 5 and 7 are about four times as thick as no.23, the parallelism of the movements indicates that the effect of the wind on drift dominates over that of the current in this area.

\section{ACKNOWLEDGEMENTS}

Thanks are extended to all the members of NARE 1978-79, headed by Dr Olav Orheim, for their enthusiastic efforts during the expedition. A variety of operations was necessary to get the overal1 programme going, particularly in the Wedde11 Sea and at Bouvet $\phi y a$. Thanks are also extended to Øyvind Finnekassa who handled the data, in cooperation with the Norwegian Meteorological Institute. The Norwegian drift experiment has been funded by, and planned in cooperation with, the Norwegian National Committee for GARP under the chairmanship of Dr Jack Nord $\phi$.

I am also grateful to those on board the USS Bland for deployment of the automatic station in the Weddell Sea in February 1978. Special gratitude is extended to Iceberg Transport International Ltd, Paris, for kind permission to use the drift data from their specially instrumented platform.

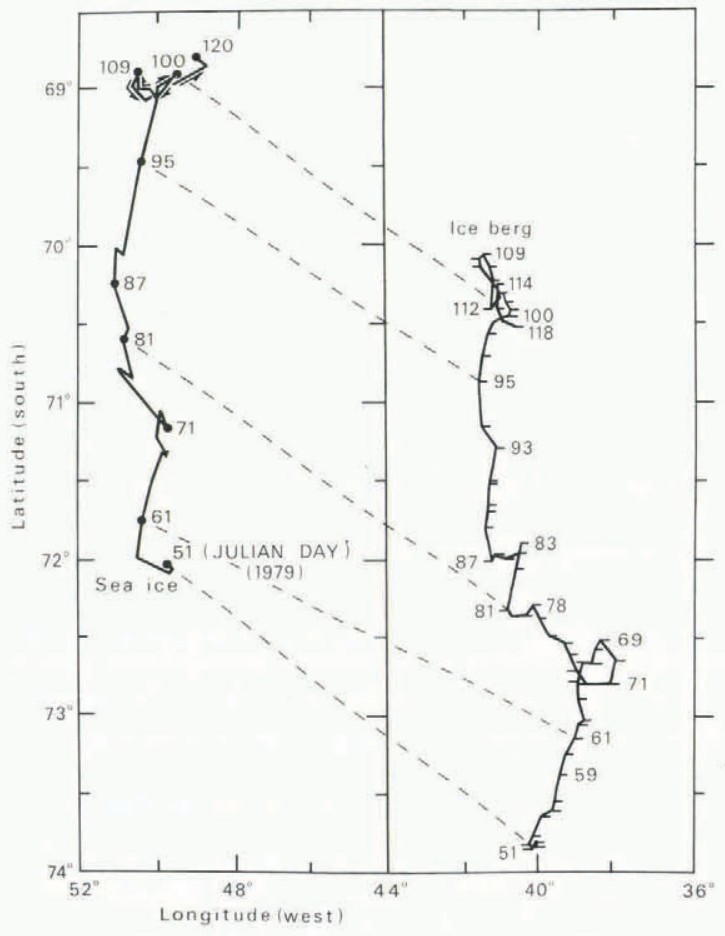

Fig. 5. Movement of sea ice (1eft) after Ackley (in press), and of iceberg no. 9 during a period of 70 days. Note the general similarity of the movements. The average speed northwards of the sea ice is 0.069 $\mathrm{m} \mathrm{s}^{-1}$ and for the iceberg $0.084 \mathrm{~m} \mathrm{~s}^{-1}$. 


\section{REFERENCES}

Ackley S F In press. Drifting buoy measurements on Wedde11 Sea pack ice. Antaretic Joumal of the United States

Hansen A E 1936 Atlas over Antarktis og Sydishavet. Sandefjord, Hvalfangernes Assuranceforening

MacClain E P 1978 Eleven year chronicle of one of the world's most gigantic icebergs. Mariners Weather Log 22(5): $328-333$

Orheim O 1980 Physical characteristics and life expectancy of tabular Antarctic icebergs. Annals of Glaciology 1 : 11-18

Romanov A A 1976 Ledovyye usloviya plavaniya $v$ vodakh Antarktiki (Ice conditions affecting navigation in Antarctic waters). Trudy Antarkticheskogo i Antarkticheskogo Nauchno-Issledovate ''skogo Instituta 335

Strübing K 1978 Trift eines bemerkenswerten Eisbergs in den Südatlantik. Seewart $39(4)$

Swithinbank C W M, MacClain E P, Little P 1977 Drift tracks of Antarctic icebergs. Polar Record 18 (116) : 495-501

Tchernia P 1974 Étude de la dérive antarctique Est-Ouest au moyen d'icebergs suivis par la satellite Éole. Comptes Rendus Hebdomadaires des Sáances de l'Academie des Sciences (Paris) Sér B 278 (14): 667670 .

Treshnikov A F 1964 Tsirkulyatsiya poverkhnostnykh vod Yuzhnogo Ledovitogo okeana (Circulation of surface waters of the Southern Ocean). Informatsionnyy ByulZeten' Sovetskoy Antarkticheskoy Ekspeditsii 45: 5-8 (English translation: Soviet Antarctic Expedition Information BuzZetin 5(2) 1965: 81-83)

Vinje T E 1977 Drift av Trolltunga i Weddellhavet. Norsk Polarinstitutt. Arbok 1975: 213

Vinje T E 1979 On the drift ice conditions in the Atlantic sector of the Antarctic. In POAC 79: the fifth International Conference on Port and Ocean Engineering under Arctic Conditions, Trondheim, Norway, 1979. Proceedings Vol 3. Trondheim, University of Trondheim, Norwegian Institute of Technology: 75-82.

Vinje T E, Finnekåsa $\emptyset$ In press. On the ice transport through the Fram strait. Norsk Polarinstitutt. Skrifter 